\title{
Corporate Failure in the Banking Sector: The Role of External
} Auditors

\author{
Joseph Kwasi Agyemang ${ }^{1 *} \quad$ Barjoyai Bin Bardai ${ }^{2} \quad$ Samuel Ntoah-Boadi ${ }^{3}$ \\ 1. Department of Accounting, Faculty of Commerce, University of Eswatini, Eswatini \\ 2. Department of Accounting, Faculty of Finance and Administrative Science, Al-Madinah International \\ University, Malaysia \\ 3. Department of Accountancy, Sunyani Technical University, Ghana
}

\begin{abstract}
The aim of the study was to establish the role of external auditors in corporate failure in the banking sector. The study discovered that the auditing gaps within banks are tangibility and empathy services. It was also revealed that remuneration, training of external auditors, lot of variety in their job, level of logistics, loyalty rate of external auditors, motivational package and improved salary and opinion counts in the organisation were the factors influencing the effectiveness of external auditors. Lastly, unethical behavior has a positive relationship with corporate failure which was statistically significant at confident interval of 0.05 with a predictive power of 83.7 percent chance of predicting corporate failure which was moderate. It was recommended that the Bank should take steps to train and promote external auditors towards acquiring the necessary skills and experience to commission the corporate failure audit. Additionally, assistance also could be sought from other Supreme Audit Institutions in other countries with a similar government arrangement. Alternatively, assistance from private audit firms that have developed expertise in the public sector audit can be sought to assist them to make the audit function more meaningful and constructive. This will help fill the empathic gap of clients. With the current trend towards the harmonization of auditing standards and guidelines, further research into the usefulness and adequacy of auditing standards and guidelines is worthwhile.
\end{abstract}

Keywords: Corporate failure, auditing, corporate corruption, assurance, effectiveness

DOI: $10.7176 / \mathrm{RJFA} / 11-4-03$

Publication date: February $29^{\text {th }} 2020$

\subsection{Background to the study}

Corporate failure has remained a threat to sustained economic growth around the globe. This is made worse considering the contemporary global business networks. Despite the evolution of corporate governance practices and other strategic managerial and stakeholders' actions, failure of firms to meet desired stakeholders' objectives has shown a prominent phenomenon (Olabiyi, 2014). Laiya, (2013) mentioned that the imposing challenge of managing organizations to meet it stated objectives in developing nations like Ghana has prescribed a reflection of the cultural circumstance as central to failure of organization.

Considering the grievous economic consequences of these failures which often times are of permanent nature, different strategic efforts have also been put in place to ensure survival and growth. Of course, the effects are characteristically multi-faceted (Phillips, 2014). As earlier noted, attempts at understanding the dynamics of business failure have attracted a multi-disciplinary approach. There are however strategic initiatives offered across all functional aspects of business (Tosin, 2014).

An important aspect in business literature has linked corporate failure to poor strategy implementation and perhaps poor operationalization of strategic actions. Low volume of operational funds has also been found in literature as having a relationship with business failure ( Daso, 2013). However, the role of external auditor is yet to form an empirical focus on the reason for corporate failure irrespective of its consideration as strategic resource for business decision making through its ability to provide information. To fill this gap, this study takes an incisive focus on the relationship between external auditors unethical behaviour and corporate business failure especially in developing economies with perhaps challenging ethical professional and socio-cultural issues.

External Auditors are professionally qualified accountants who are involved in public practice. They are described as chartered; qualified; certified or registered Accountants who are engaged by the owners of a company to represent their interest. According to Section 134 of the Companies Code 1963 (Act 179) of Ghana, every company shall at each Annual General Meeting appoint an auditor or auditors to audit the financial statements of the company, and to hold office from the conclusion of that, until the conclusion of the next annual general meeting. This in all sense spells the critical and legitimate role of auditors in ensuring corporate survival. Of course, their reports provide relevant information for strategic business decisions that are applicable at all levels.

According to section 136 of the Companies Code 1963 (Act 179) of Ghana, it is the duty of the external auditor to report on the accounts which the directors are obliged to prepare and present to the shareholders. The auditor of a company not only has a responsibility to the shareholders but also has a duty of care, skill and diligence to third parties such as creditors and potential investors. Principally, the external auditor forms and expresses an 
independent opinion as to whether accounts give a true and fair view of the state of affairs at the balance sheet date and of the profit or loss for the period.

Bibeault (2014) identifies corporate failure from four stand points namely, social, economic, legal and managerial. They social standpoint he argues, is in terms of its impact. That is, the human suffering that such a phenomenon usually brings, it affects almost everyone: the owners, employees, government, customers, investors, suppliers, creditors and the society in general. However, not everyone agrees that the longer-range social impact of corporate failure is negative. The economic standpoint viewed failure as a situation whereby the realized rate of return on investment capital is significantly and continually lower than prevailing rates on similar investments. In fact, a company could be an economic failure for years and yet, in the absence of legally enforceable debt, be able to meet its current obligations. This view of failure is however subjective, and there are very few data available on industry or company incidence of economic failure.

Legally, a company is declared as a failure if it is not able to meet its current obligations and settling its outstanding debts. Thus, failure is synonymous with insolvency and bankruptcy, (Benston, et al, 2014). Glaessner and $\mathrm{Ma}$ (2001), on the contrary, opined that insolvency is officially recognized and the organization is closed. A business can also be a failure from a managerial standpoint before it is an economic failure and certainly long before a legal failure. Managerial failure is measure by a long period of decline and leading to large write-offs and to losses at the bottom line, which culminate into intense pressure for a change in management.

There is therefore a considerable degree of consensus that the quality of management makes the difference between sound and unsound organizations. Most of the corporate failures that result in different organizations are as a result of mismanagement of resources and virtually every aspect of mismanagement of resources comes as a result of non-compliance to policies and virtually every aspect of the organization's regulations.

Corporate failure has continued to dominate the entire corporate environment throughout the World, and Ghana is not an exception. This has elicited continuous outcry about corporate survival; and the blame is always shifted to corporate management on the account of its failure to harness and use available resources effectively and efficiently for good corporate objectives (Friday et al., 2014). Thus, there is an increasing lack of confidence on corporate management. A study by Friday et al., (2014) asserted that, the negligence of external auditors' role in corporate failure has however open door for the criticism of corporate management in this regards.

Kimbro (2002) argued that the probability of detecting corruption could increase by increasing accountability, transparency, independent oversight, audits, and information access. Brown, Smith, White and Zutter (2013) investigated the relationship between political corruption and firm value. The findings revealed that strong audit monitoring can mitigate the negative firm value effects of political corruption within the U.S.

Lamoreaux, Michas, and Schultz (2015) investigated the role of accounting and audit quality in the allocation of international development aid loans provided by the World Bank. The findings indicate that the amount of aid lent by the World Bank to a country is higher for countries with stronger accounting and audit quality. The study also found that accounting and audit quality are associated with World Bank lending only in countries with relatively high level of corruption. Although evidence from prior literature showed that sound external audits could help in combating corruption, there is still a huge gap of knowledge in this area especially when it comes to the responsibility of external auditors with regards to corporate corruption and how external auditors could actually assess and respond to corruption risks.

Low volume of operational funds has also been found in literature as having a relationship with business failure (Stain, 2014; Fubara, 2014; Daso, 2013). However, the role of external auditor is yet to form an empirical focus on the reason for corporate failure irrespective of its consideration as strategic resource for business decision making through its ability to provide information. To fill this gap, this study takes an incisive focus on the relationship between external auditors' unethical behaviour and corporate business failure especially in developing economies with perhaps challenging ethical professional and socio-cultural issues.

Auditors' reports add credibility to the financial reporting by ensuring that accounting statements follow the generally accepted guidelines and are accurate, but when the auditor's performance is below public expectations then the signature together with the brief opinion of the auditor will no longer be useful to decision makers. Therefore, this study assessed the contribution of external auditors in corporate failure within the Ghanaian financial sector with special focus on some selected financial firms. The study looked at the role played by external auditors in corporate failure within the Ghanaian financial sector. The study was conducted on some selected financial firms within the Kumasi Metropolis. Kumasi Metropolis was chosen because of its accessibility of banks. The study was limited to the expectation, perception of staff about the role of external auditors in financial firms that has experienced corporate failure before. The unethical behaviors of external auditors were also discussed. Specifically, the study sought to achieve the following objectives:

i. To determine the perception and expectation about the role of external auditors.

ii. To identify the unethical behaviour of external auditors.

iii. To establish the relationship between unethical behaviour of external auditors and corporate failure. 


\subsection{Literature review}

\subsubsection{Concept of auditing}

Auditing is an independent function by means of an ordered and structured series of steps, critically examining the assertions made by an individual or organization about economic activities in which they are engaged and communicate the results in the form of a report to the users (Salehi, 2011). According to the American Accounting Association (AAA) (1973), auditing is defined as "a systemic process of objectively obtaining and evaluating evidence regarding assertions about economic actions and events to ascertain the degree of correspondence between those assertions and established criteria and communicating the results to interested users". "The process by which a competent, independent person accumulates evidence about quantifiable information related to a specific economic entity for the purpose of determining and reporting on the degree of correspondence between the quantifiable information and established criteria"(Arens et al., 1997). On the other hand, Mautz and Sharaf (1986) defined auditing as being "concerned with the verification of accounting data, which determines the accuracy and reliability of accounting statements and reports".

\subsection{Theoretical framework}

\subsubsection{Agency theory}

The agency theory explains the conflict of interest created by the agent (management) and the principal (shareholders) and how this needs to be managed. Historically, businesses were owned and managed by the same persons. However, for economies to grow and expand it was necessary to find a larger number of investors to provide finance in order to assist in this regard. Ultimately this led to the concept of limited liability companies and subsequently the development of stock markets in order to buy and sell shares. According to Jensen and Meckling (1976), the agent (managers) undertakes to perform certain duties for the principal (investors) and the principal in turn undertakes to reward the agent. In this regard, agency costs are incurred by principals in order to monitor the agency behavior (both in terms of management remunerations and auditor's remunerations) all because of the lack of trust in the good faith of agents. The role of the auditor is to supervise the relationship between the management and the shareholders. For Andresson and Emander (2005), a gap expectation occurs when the distribution of the responsibility is not well defined.

The responsibility of every part is well defined in the regulation. Therefore, the management and the shareholders have to realize that the auditor does not have responsibility of accounting, but instead only see that the auditing is carried out properly. As cited in Adeyemi and Uadiale (2011), Hermanson et al. (1993) identify four (4) conditions in the business environment which create a demand for an independent audit. These are conflict of interest, consequence, complexity, and remoteness.

In view of Conflict of interest, financial statement users want the statements to show the company's financial performance, position and statement of cash flows as accurately as possible. Also, educators' users of the financial statements know that it is the company's director's responsibility to prepare financial statements reflecting their own performance. Therefore, there is a perceived perception from users of financial statements that the directors may bias their report so as to reflect favorably on their management of the company's affairs. From the above statements it can clearly be seen that there is a potential conflict of interest between the preparers (directors of the company) on one hand, and the users of the financial statements on the other. Therefore, the external auditors play a significant role in assisting to ensure that directors provide, and users are confident of receiving, information which is fair representation of the company's financial statements (Obiri, 2011).

Again, there is no doubt that audited financial statements are used by wide range of users in making informed economic decisions; and as such the auditors' works add credibility to the financial statements by giving users the needed assurances and peace of mind. To this end, if users of a company's financial statements base their decisions on unreliable information, they suffer serious financial loss. In the collapse of Enron, the investors lost an estimated USD\$61 billion (Kroger, 2004, Salifu, 2014).

Furthermore, Salehi (2011) argues that the information communicated by companies has become more complex, users of the information have found it more difficult or even impossible, and to obtain direct assurances about the quality of the information received. Additionally, Nogbondari and Foong (2013) indicate that with the increasing complexity of transactions, accounting systems and financial statements, users of external financial statements are less able to evaluate the quality of the information for themselves. Furthermore, the growth in size of companies means a corresponding growth in the volume of their transactions as well, and as such errors are more likely to crap into accounting data (knowingly or unknowingly) and these affects the financial statements. This certainly calls for a need for the financial statements to be examined by an independent qualified auditor, who has the necessary competence and expertise to understand the entity's business, its transactions and its accounting system as opposed to users without such expertise.

Moreover, as a consequence of legal, physical and economic factor, users of a company's external financial statements are not able to verify for themselves the reliability of the information contained in the financial statements (Adeyemi and Uadiale, 2011). However, if users are majority shareholders in an entity, they have de 
facto right of access to the company's books and records. Remoteness basically is caused by the separation of the user of the information and the source of the information. In other words, remoteness actually prevents the users of the information from assessing directly the quality of the information.

\subsubsection{Expectation theory of auditing}

The expectation theory of auditing can be explained in terms of the expectation gap. The audit expectation gap is not a new phenomenon in the auditing literature, and as a result several researchers in this field have defined the subject over time. However, the audit expectation gap somewhat gives a bad reputation though to the external auditors. One would ask why this old problem (audit expectation gap) between users of the financial statements and the auditing profession has remained unresolved all these years. Well, corporate failures in recent times both at national and international dimensions have further undermined the credibility of auditing practices and its related regulation. In the bankruptcy of WorldCom, $40 \%$ of employee plans consisted WorldCom stocks were lost. Salehi (2011) indicates that when WorldCom went bankrupt, employees lost USD\$775 million in interest benefits. Additionally, the events of scandals not only caused an erosion of confidence in the capital market but also created what Whittington and Pany (2004, p. 10) call a "crises of credibility" for the accounting profession cited in (Salehi, 2011).

According to Ojo (2006), the issue revolving round the expectations gap debate relates to the different and inconsistent meanings attributed to the definition of an audit by users of financial statements, the public and the audit profession. The "expectations gap" is the difference between what the public and users of financial statements perceive the role of an audit to be and what the audit profession claim is expected of them during the conduct of an audit (Ojo, 2006).

Pierce and Kilcommins (1996 cited in Ojo, 2006) defined the audit expectations gap as when external auditors' understanding of their role and duties is compared against the expectations of user groups and the general public. Liggio in 1974 (cited in Adeyemi \& Uadiale, 2011) defined the audit expectations gap as the difference between the levels of expected performance as envisioned by users of a financial statement and the independent accountant.

\subsection{Empirical review}

\subsubsection{Corporate failure}

Altman (2004) mentioned that there is no unique definition of corporate failure exists. Possible definitions range from failure to earn an economic rate of return on invested capital, to legal bankruptcy, followed by liquidation of the firms, assets. Continuing, he opined that corporate failure refers to companies ceasing operations following its inability to make profit bring in enough revenue to cover its expenses. This can occur as a result of poor management skills, inability to compete or even insufficient marketing. However, this may represent the end of a period of financial decline, characterized by a series of losses and reducing liquidity. Any attempt to uniquely define corporate failure is likely to prove problematic.

Grisat as cited by Bibeauty (1999), some companies never have a reason to exist in the first place. According to the author, in a lot of markets, this is room for two or three companies and no more. Many organizations that either refuse or lack the resources to adapt in an atmosphere of growing competition and immeasurably increasing sophistication; end up being edged out of business. In his own contribution, Afolabi (1994) argues that firms without avowed objectives and target make performance difficult to be judged.

\subsection{The role of external auditors in corporate corruption}

Our review has also shown that only a few studies have examined the role of external auditors and/or the audit profession in combating corruption and corporate failure. Indeed, no study seen by the authors has actually examined the responsibilities of the external auditors in relation to corruption. For instance, Uecker, Brief, and Kinney (1981) investigated whether managers' perceptions of external auditor serve as a deterrent to corporate irregularities. However, their results did not support this hypothesis. The authors suggested that external auditors are expected to make additional efforts to detect irregularities to change management perception. Some of the few relevant studies found were Albrecht, Malagueno, Holland, and Sanders' (2012) investigation of whether the existence of a professional oversight body and specific education regulations were associated with a country's perceived level of corruption. Their findings revealed that countries that have established an audit profession oversight body are perceived to be less corrupt. They also found that countries requiring practical experience, academic study, and a licensing examination in order to practice auditing are perceived to be less corrupt.

An effective audit function will add value and improve an organization's operations. Oxford Dictionary defines effective as having an effect or able to bring about the result intended. Dittenhofer (2001) and Omar, et al. (2007) defined effectiveness as the achievement of the objectives and goals. Beckmerhagen, et al. (2004) stated that in order to adequately measure audit effectiveness, evaluation must not be done only on results of the audit against the planned objectives, but also the audit process (planning, execution to reporting and follow-up) and resources (auditor independence and competence). Omar, et al. (2007) explained that the effectiveness concept in the public sector focuses on the outcome or impact of a program or activity rendered to the public. A program is 
said to be effective if its outcome met its objective(s).

Sterck and Bouckaert (2006) mentioned that the implementation of internal audit function in the public sector is most effective when there is (1) legal requirement for the establishment of internal audit function, (2) strategy for the development of competency of internal audit function staff, (3) support from top management and existence of audit committee, and (4) central unit for the advancement of the internal audit function. Once, the implementation of internal audit function is successful, building it to be effective is another challenge that needs to be overcome.

Six main themes have been identified by (Van-Gansberghe, 2005) as crucial in building an effective internal audit function and they are: perception and ownership, organization and governance framework, legislation, improved professionalism, a conceptual framework, and resources.

Mihret and Yismaw (2007) identify factors within an organization that impact on audit effectiveness. The results show that organizational setting and the auditors' attributes do not have a strong impact on audit effectiveness. However, internal audit quality and management support are two attributes that strongly influenced the internal audit effectiveness.

In the private sector, Hung and Han (1998) investigated the factors that influence the effectiveness of internal auditing for listed firms in Taiwan. The findings showed that on average, regular performance evaluation of internal auditors, positive attitude of controller to internal auditing job, and well-designed education and training of internal auditors are useful to enhance the management perceived performance. However, professionalism is useful to increase the audited department head's perception of performance. The results also implied that both inside and outside internal auditing department have some factors that influence the progress of annual audit plan. In identifying the factors that influence the effectiveness of internal auditing, different questionnaires were mailed to the general manager, the head of audited department and the head of internal auditing department of each company.

Contrast to the study by Hung and Han (1998), Annuar, et al. (2001) only solicited the opinion of the internal auditors to provide information on important factors that contribute towards the effectiveness of an internal audit function among Malaysian listed firms. Interpersonal skills, internal auditor's commitment and support from audit committee and BOD, audit performance and integrity, audit department efficiency, auditing competencies, internal auditor's knowledge on company's business operation and industry and auditor's independence are found to be important attributes contributing towards internal audit function effectiveness. Annuar, et al. (2001 opined that unethical behaviour of auditors will contribute to corporate failure.

\subsection{Responsibilities of External Auditors in Relation to Corporate Corruption}

An examination of the audit standards revealed that although the efforts of audit regulators in combating fraud cannot be denied, little attention has been given to external auditors' responsibilities with regards to corporate corruption. For instance, in relation to fraud, the International Auditing and Assurance Standards Board (IAASB) issued the International Standard on Auditing (ISA) 200, Overall Objectives of the Independent Auditor and the Conduct of an Audit in Accordance with International Standards on Auditing (IAASB 2007), and ISA 240, The Auditor's Responsibility Relating to Fraud in an Audit of Financial Statements (IAASB 2009a). The Auditing Standards Board (ASB) of the American Institute of Certified Public Accountants (AICPA) issued the Statement on Auditing Standard (SAS) 99 Consideration of Fraud in a Financial Statement Audit in 2002 (ASB 2002). The Public Company Accounting Oversight Board (PCAOB) also issued AU Section 316 Consideration of Fraud in a Financial Statement Audit (PCAOB 2002). However, none of these audit standards make a direct reference to external auditors' responsibilities with regards to corporate corruption that was only implicitly implied and, in some instances, seemingly ignored, assuming that corruption has no impact on the financial statements.

ISA 200 stated that "external auditors are responsible for detecting material misstatements whether due to errors or fraud" (IAASB 2007, 3, para. 5). Given that corruption is a type of internal fraud (Wells 2005), external auditors are likely responsible for detecting material misstatements arising from it. However, this was again ignored by ISA 240 (IAASB 2009a), and SAS 99 that require external auditors to assess and respond to fraud risks arising from only two types of internal fraud, "asset misappropriation and financial reporting fraud" (ASB 2002). ISA 240 justified this by stating that asset misappropriation and financial reporting fraud are more likely to have an impact on the financial statements (IAASB 2009a, para. A1-A6). SAS 99 did not explain its rationale. This indicates that both standards assume that corruption does not have an impact on the financial statements although evidence from prior literature seems to show otherwise.

Pacini, Swingen, and Rogers (2002) stated that transparency in financial reporting is impaired by bribery activities. Corrupt employees can cause employers to overpay for goods and services bought by a company in which the employees have a hidden interest. This form of corruption is called "conflict of interest." These conflicts of interest can also lead to writing off sales through the use of discounts or allowances. Inadequate disclosure of conflicts of interest and related parties transactions could also have an impact on the financial statements and may mislead shareholders. Corrupt payments could be made by normal business checks. Disguised 
payments on the payer's accounting records might appear as some sort of legitimate business expense such as consulting fees. Loans and credit card expenses could also be used as a form of bribe (ACFE 2012). Corruption could have an impact on the financial statements because of the procurement of high-value goods and services. In addition, most bribery involves disbursement of cash and the recording of that disbursement in the financial records (IIA 2014; Wells 2011). Other accounts that could be affected by corruption include petty cash, gifts, travel and entertainment payments, reimbursements, accounts receivable, donations, and sales contracts (IIA 2014).

Payments of bribes recorded in the accounting records are more likely to be in the form of fictitious payables, false purchases, ghost employees, interest-free loans, fictitious bids, or overbilling (Vona 2008; Wells 2011). Cooper and Fargher (2011) considered that the concealment of bribes can take place through charging the company for services that were not performed, invoicing the company at an inflated rate, or in the form of loans, accounts receivable, or bonus payments to corporate officers. This results in misrepresentation of expenses and assets in the financial statements that could also be material. In FASB Statement 2, materiality was defined as "the magnitude of an omission or misstatement of accounting information that, in the light of surrounding circumstances, makes it probable that the judgment of a reasonable person relying on the information would have been changed or influenced by the omission or misstatement" (FASB 1980, 10). As corruption is an illegal act, its concealment would be because knowledge of it would influence "the judgment of a reasonable person." The knowledge of a corrupt act is probably more important than the absolute size of the transgression.

However, both standards did not directly refer to corruption or the responsibilities of the external auditors with regards to corruption. It was not also clear how external auditors could decide on whether an illegal act has a direct or indirect impact on the financial statements. ISA 250 provided some examples of indicators for noncompliance with laws and regulations that external auditors need to consider (IAASB 2009b, para. A13) that were similar to examples of red flags of bribery cited by Wells (2005) in his book Principles of Fraud Examination such as: "cases when low-bid awards are frequently followed by changed orders or amendments that significantly increase payments to the vendor," "unusual or unexplained fluctuation in payables, expenses or disbursements," " "unusually high price contracts for goods or services purchased by the company," and "improper or unauthorized payment for goods or services." This indicates that the standard implicitly required external auditors to assess and respond to bribery and corruption risks as long as it has a material impact on the financial statements; however, this was not directly mentioned in the audit standards. This lack of clarity about the responsibilities of external auditors with regards to corporate corruption could make external auditors overlook their responsibility for detecting material corruption that could have an impact on the financial statements since this was not explicitly required by audit standards. This might increase auditors' liability and litigation costs. It might also result in inconsistency in complying with the requirements of the audit standards for illegal acts.

\subsection{Experience of the internal audit and firm performance}

The third value of IAC is experience of internal audit. When a person has many years of experience, he/she can make a right decision, decide fast and deal with any situation. This variable is measured by the number of years the members have gathered through a questionnaire that is sent to every firm by email. Consistent with the resource dependence theory and its proponents, expert individuals help in firm growth because they have a clear insight about how to deal with process and accomplish their tasks with superior quality. And when the firm provides a board with high experts, they help to understand external environment and as a result, will improve performance of companies. There are few studies that examined the relationship between the experience of internal audit and firm performance in both developed countries and developing countries. There is also lack of studies among the developing emerging markets. Few studies are discussed below in light of this association.

Hutchinson and Zain (2009) explored the association between internal (audit experience and accounting qualification) audit and firm performance (ROA) with growth opportunities and audit committee independence in Malaysia. The sample was selected by two methods namely questionnaire and secondary data from the annual reports. It involved 60 firms which were listed on Malaysia Bursa in 2003. This study used multiple regression analysis to test the association between internal audit and firm performance and found a significant relationship between experience of internal audit quality and firm performance.

Prawitt, Smith and Wood (2009) examined the association between internal audit quality (experience and qualification) and earnings management. This study obtained sufficient data to estimate abnormal accrual models for 528 firm-year observations (218 unique companies) for the fiscal years 2000 to 2005. It used OLS regression to test the association between independent variables and dependent variable. The finding shows that a relationship between experience of internal audit and earning management. As mentioned above, there is a lack of studies examining the relationship between the experience of internal audit and firm performance. Moreover, Al-Matari et al. (2012) recommended the re-examination of the relationship between the experience of internal audit and firm performance. 


\subsection{Research methodology}

This study employed descriptive and explanatory designs. Descriptive data are usually collected through questionnaires, interviews or observations. Descriptive survey helps in describing, observing and documenting aspects of a situation as it is naturally. This study employed quantitative approach, to achieve the stated objectives. In this research using quantitative approach to explain the effectiveness of internal auditors was assumed to be more reliable. The population of this study comprises all banks that have experienced corporate failure in Ghana and external auditors to those banks. According to bank of Ghana Report (2018), a total of 16 universal banks which once operated in the country have been collapsed within two years as part of measures taken by the Bank of Ghana to cleanse the banking sector to make it more robust.

The study's sample frame comprises external auditors and existing staff of banks that have experienced corporate failure within the Kumasi Metropolis. The sample size was determined by the sample size determination formula used by Kashmala and Faiza, (2015). The total population of external auditors and existing staff of banks that have experienced corporate failure within the Kumasi Metropolis were estimated to be 340 respondents. Where

$$
\begin{gathered}
n=\frac{P}{1+P \varepsilon^{2}} \\
n=\frac{340}{1+340\left(0.05^{2}\right)}=184 \\
\varepsilon=\text { margin of error } / \text { confidence level }
\end{gathered}
$$

$n=$ sample size

$$
P=\text { Population size }
$$

A sample size of one hundred and eighty-four (184) respondents was selected from the total population of 340 respondents. The sampled size comprised, five (5) external auditing firms with 40 staff in total and 144 staff of collapsed Universal Banks in Kumasi Metropolis now merged into Consolidated Bank Ghana (CBG). Staff members were selected through purposive sampling technique. Agyemang, Wingard and Acheampong (2019) indicated that ppurposive sampling is a non-probability sampling method and it occurs when elements selected for the sample are chosen by the judgment of the researcher. The study adopted purposive sampling technique because the researchers were interested in staff members who had knowledge about the area been studied and have been in existing during the failure of the bank. The study employed primary source of data. Primary data for the study were collected through questionnaire. The closed and opened ended questionnaire was designed in order to enable the researcher accomplish the research objectives. A section of the questionnaire employed a five-point Likert scale to measure the degree of staff members' responses across three dimensions. The key are as follows: $1=$ Strongly agree, 2 = Agree, $3=$ Neutral, $4=$ Disagree, $5=$ Strongly disagree. Again, the questionnaire that was designed to solicit the opinions of junior staff and senior staff who were primarily involved in the area been researched. Data was analysed with SPSS 21.0 version and Microsoft Office Excel 2016 to obtain graphs and Tables. This was to identify trends that appeared from responses. Descriptive statistics and other regression concepts were employed to justify the responses of respondents.

\subsection{Model specification}

Where:

$$
C F_{i}=\beta_{0}+\beta_{1}(R E)_{i}++\beta_{2}(R E S)_{i}++\beta_{3}(A S S)_{i}++\beta_{4}(E M)_{i}+\beta_{5}(T A N)_{i}+\alpha_{i}
$$

$\mathrm{CF}=$ Corporate failure

Reliability $=\mathrm{RE}$

Responsiveness $=$ RES

Assurance $=$ ASS

Empathy $=$ EM

Tangibles $=$ TAN

$\beta_{0} \beta_{1} \beta_{2} \beta_{3} \beta_{4}=$ coefficients of regression

$\alpha_{i}=$ error term

Descriptive statistics model provides the researcher with the 'summary' statistics such as mean, median and standard deviation which explain the responses of the junior and senior staff of the bank. On the descriptive statistics Table, the higher the value of the mean, the higher the disagreement with the statement: The scale is as follows: One $=$ Strongly agree, Two $=$ Agree, Three $=$ Neutral, Four $=$ Disagree, Five $=$ Strongly disagree

\subsection{Data analysis and discussion of findings}

\subsection{Measuring the perception and expectation about effectiveness of external auditors}

In view of the analysis, auditing effectiveness gap was defined as the difference between organization expectations of external auditors understanding of those expectations and designing strategies necessary to meet those expectations (organization perception). In the quest to assess the perception and expectation about effectiveness 
of external auditors at Bank, the analysis was carried out in two phases. For the first phase, respondents were asked to indicate their preference by either indicating very important, important, Neutral, Not Important, Not all important on various statements pertaining to organization expectation about the bank's external auditors. The second phase was done by allowing respondents to strongly-agree, agree, neutral, disagree, strongly-disagree on the various statement pertaining to extent to which their expectation on external auditing was met at the bank(perception). Their responses are analysed and presented in the descriptive statistics table below:

Table 4.1: Descriptive Statistics on Staff' expectation about external auditors' effectiveness.

\begin{tabular}{|l|c|c|c|c|c|}
\hline & $\mathrm{N}$ & Minimum & Maximum & Mean & Std. Deviation \\
\hline Reliability & 144 & 1.00 & 5.00 & 4.630 & .63012 \\
Assurance & 144 & 1.00 & 5.00 & 4.830 & .97576 \\
Tangible & 144 & 1.00 & 4.00 & 3.833 & .77145 \\
Empathy & 144 & 1.00 & 5.00 & 4.963 & 1.42146 \\
Responsiveness & 144 & 1.00 & 5.00 & 4.557 & .75789 \\
Valid N (listwise) & 144 & & & & \\
\hline
\end{tabular}

\section{Source: Authors Computation, 2019}

From table 4.1, respondents revealed that it was very important for external auditors to be reliable in their service delivery. Thus, external auditors should ensure those organizations are given the necessary information as prescribed. Also, external auditors are to be dependable when handling organization problems. Again, external auditors must be people that can be trusted with organization confidentiality and lastly, external auditors should ensure that organization do not spend too much time waiting in queues and where there are delays explanations are to be given. The mean for this item is 4.6300 approximately 5 (very important).

Additionally, in Table 4.1 above, organization revealed that it was very important for external auditors to create assurance atmosphere of good service delivery. Thus, external auditors should be courteous and friendly to organization. Also, external auditors must be able to inspire trust and confidence in organization. Again, external auditors should ensure that, transactions are made on time and that no mistakes are made with transaction process. Lastly, external auditors must create a friendly atmosphere for organization to feel safe and relaxed. The mean for this item is 4.8 approximately 5 (very important).

Furthermore, Table 4.1 above revealed that, it was important for external auditors to be tangible in their delivery of service. Thus, external auditors should be well dressed at all times with the external auditors operating with modern auditing equipment. Also, the external auditors need to have visually attractive and comfortable physical facility (thus chairs, table) with appealing materials (i.e brochures, magazines, newspapers etc) to engage organization as they wait for auditing. Lastly, there should be directional signs to help organization with easy navigation and also the auditing structures should be disability friendly, the mean for this item is 3.8 approximately 4 (important).

Moreover, table 4.1 above revealed that it was very important for external auditors to be empathic in their service delivery. Thus, External auditors should be patient when dealing with organization and also should not be reluctant when responding to organization complaints. Again, external auditors should take time to listen to organization and remember names and faces of organization. Lastly, external auditors should ensure organization feel good emotionally and psychologically. The mean for this item is 4.9 approximately 5 (very important).

Lastly, Table 4.1 above revealed that it was very important for external auditors to be responsive in their service delivery. Thus, external auditors should always be able and ready to receive organization and willing to help organization even during odd hours. Lastly, external auditors should have organization interest at heart. The mean for this item was 4.55 approximately 5 (very important). In summary the auditing gap identified here was the empathy service. This finding is in support of Hung and Han (1998). Hung and Han (1998 findings showed that on average, regular performance evaluation of internal auditors, positive attitude of controller to internal auditing job, and well-designed education and training of internal auditors are useful to enhance the management perceived performance. However, professionalism is useful to increase the audited department head's perception of performance. 
Table 4.2: Descriptive Statistics on non- auditors' perception of external auditors service delivery.

\begin{tabular}{|l|c|c|c|c|c|c|}
\hline & $\mathrm{N}$ & Minimum & Maximum & Mean & Std. Deviation & \\
\hline Reliability & 144 & 1.00 & 5.00 & 4.970 & .55432 & 4.630 \\
Assurance & 144 & 1.00 & 5.00 & 4.860 & .79135 & 4.830 \\
Tangible & 144 & 1.00 & 5.00 & 4.245 & .59018 & 3.833 \\
Empathy & 144 & 1.00 & 4.00 & 3.664 & .84907 & 4.963 \\
Responsiveness & 144 & 1.00 & 4.00 & 4.587 & 0.85907 & 4.557 \\
Valid N (listwise) & 144 & & & & & \\
\hline
\end{tabular}

Source: Authors Computation, 2019

In assessing the auditing gap within Bank, Staff revealed that external auditors were reliable in their service delivery. Thus, strongly agreeing that, external auditors ensure organization goes through auditing process as prescribed. Also, external auditors are dependable when handling organization problems. Again, external auditors are people they can trust with organization confidentiality and lastly, external auditors ensure that organization does not spend too much time waiting in queues and where there are delays explanations are given. The mean for this item is 4.970 approximately 5 (strongly agreed).

Additionally, in assessing the auditing gap within Bank, Table 4.2 above revealed that external auditors assured organization of good service delivery. Thus, external auditors were courteous and friendly to organization. Also, external auditors were able to inspire trust and confidence in organization. Again, external auditors ensure that, auditing process are carried out on time and that no mistakes are made with the auditing process. Lastly, external auditors create a friendly atmosphere for organization to feel safe and relaxed. The mean for this item is 4.86 approximately 5 (strongly agree).

Furthermore, Table 4.2 above revealed that respondents strongly agreed with the statement that, external auditors were tangible in their delivery of service. Thus, external auditors are well dressed at all times and also operating with modern auditing resources. Also, the external auditors have visually attractive and comfortable physical facility (i.e chairs, table) with appealing materials (i.e brochures, magazines, newspapers etc) to engage organization as they wait to be audited. Lastly, there were directional signs to help organization with easy navigation and also the external auditors' structures were disability friendly, the mean for this item is 4.25 approximately 4 (agreed).

Moreover, Table 4.2 above revealed that respondents agree with the statement that external auditors were empathic in their service delivery to some extent. Thus, external auditors were patient when dealing with the organization and also were not reluctant when responding to organization complaints. Again, external auditors take time to listen to organization and remember names and faces of organization.

Lastly, an auditor ensures organization feel good emotionally and psychologically. The mean for this item is 3.66 approximately 4 (agreed). Lastly, table above revealed that respondents agreed with the statement that external auditors were responsive in their service delivery. Thus, external auditors were always able and ready to receive organization and willing to help organization even during odd hours. Lastly, external auditors have organization interest at heart. The mean for this item was 3.66 approximately 4 (agree). In summary the auditing gap identified here was the empathy service. This finding affirms Beckmerhagen, et al. (2004). The authors stated that in order to adequately measure audit effectiveness, evaluation must not be done only on results of the audit against the planned objectives, but also the audit process (planning, execution to reporting and follow-up) and resources (auditor independence and competence) 
4.2 Examining the gap between what staff perceived and their expectation about external auditors' service delivery

Table 4.3: The gap between what staff perceived and their expectation about external auditors' service delivery

\begin{tabular}{|l|c|c|c|}
\hline \multicolumn{1}{|c|}{ Services } & Mean perception & Mean of expectation & $\begin{array}{l}\text { Difference between mean of } \\
\text { perception and expectation }\end{array}$ \\
\hline Reliability & 4.970 & 4.630 & 0.34 \\
Assurance & 4.860 & 4.830 & 0.03 \\
Tangible & 4.245 & 3.833 & 0.41 \\
Empathy & 3.664 & 4.963 & -1.30 \\
Responsiveness & 4.587 & 4.557 & 0.03 \\
Valid N (listwise) & & & \\
\hline
\end{tabular}

Source: Authors Computation, 2019

In assessing the auditing gap within Bank, the table above established that, in terms of reliability of service Staff expectation was quite lower than Staff expectation on assurance. Thus, indicating that once external auditors are reliable to organization there is an assurance of good service delivery. This expectation was also realised at the bank thereby resulting a positive gap of 0.34 and 0.03 .

Additionally, the analysis recognized that, in terms of tangibility of service delivery by the bank Staff' expectation was quite lower than Staff expectation on empathy service delivery. Thus, indicating that external auditors are more significant than the bank structures. Implying that once they are well treated the facilities of the bank was immaterial. This expectation on empathy was not realised at the bank resulting in a negative gap of -1.3 . Lastly, the analysis recognized that, in terms of responsiveness of service delivery by external auditors, Staff expectation was quite lower than expectation on empathy service delivery. This implies that, an external auditor immediate responds to organization was paramount in service delivery and that more was expected from them. This expectation was also realised producing a positive gap of 0.03

Table 4.3: Descriptive Statistics on external auditors' expectation about external auditors service delivery

\begin{tabular}{|l|c|c|c|c|c|}
\hline & $\mathrm{N}$ & Minimum & Maximum & Mean & Std. Deviation \\
\hline Reliability & 40 & 1.00 & 5.00 & 4.2120 & 1.91356 \\
Assurance & 40 & 1.00 & 5.00 & 4.8160 & 1.47746 \\
Tangible & 40 & 1.00 & 4.00 & 3.5520 & 1.81595 \\
Empathy & 40 & 1.00 & 5.00 & 4.0960 & 2.15996 \\
Responsiveness & 40 & 1.00 & 5.00 & 4.0200 & 1.21388 \\
Valid N (listwise) & 40 & & & & \\
\hline
\end{tabular}

Source: Authors Computation, 2019

From Table 4.3 above, external auditors also revealed that it was important for them to be reliable in their service delivery. Thus, external auditors should ensure organization take the due auditing process as recommended. Also, external auditors are to be dependable when handling organization problems. Again, external auditors must be people they can trust with organization confidentiality and lastly, external auditors should ensure that organization do not spend too much time waiting in queues and where there are delays explanations are to be given. The mean for this item is 4.2 approximately 4 (important).

Additionally, in Table 4.3 above revealed that it was very important for external auditors to create assurance atmosphere of good service delivery. Thus, external auditors should be courteous and friendly to organization. Also, external auditors must be able to inspire trust and confidence in organization. Again, external auditors should ensure that, auditing process are carried out on time and that no mistakes are made with the process. Lastly, external auditors must create a friendly atmosphere for organization to feel safe and relaxed. The mean for this item is 4.8 approximately 5 (very important).

Furthermore, Table 4.3 above revealed that, it was important for the bank to be tangible in their delivery of service. Thus, external auditors should be well dressed at all times with the bank operating with modern auditing equipment. Also, external auditors need to have visually attractive and comfortable physical facilities with appealing materials (i.e brochures, magazines, newspapers etc) to engage organization as they wait. Lastly, there should be directional signs to help organization with easy navigation and also external auditors' structures should be disability friendly, the mean for this item is 3.55 approximately 4 (important).

Moreover, Table 4.3 above revealed that it was important for external auditors to be empathic in their service delivery. Thus, External auditors should be patient when dealing with organization and also should not be reluctant 
when responding to organization complaints. Again, external auditors should take time to listen to organization and remember names and faces of organization. Lastly, external auditors should ensure organization feel good emotionally and psychologically. The mean for this item is 4.0 approximately (important).

Lastly, Table 4.3 above revealed that it was important for external auditors to be responsive in their service delivery. Thus, external auditors should always able and ready to receive organization and willing to help organization even during odd hours. Lastly, external auditors should have organization interest at heart. The mean for this item was 4.02 approximately 4 (important). This finding affirms Beckmerhagen, et al. (2004). The authors stated that in order to adequately measure audit effectiveness, evaluation must not be done only on results of the audit against the planned objectives, but also the audit process (planning, responsiveness, assurance, execution to reporting and follow-up) and resources (auditor independence and competence).

Table 4.4: Descriptive Statistics on external auditors' perception of auditing

\begin{tabular}{|l|c|c|c|c|c|}
\hline & $\mathrm{N}$ & Minimum & Maximum & Mean & Std. Deviation \\
\hline Reliability & 40 & 1.00 & 5.00 & 4.8800 & 2.03941 \\
Assurance & 40 & 1.00 & 5.00 & 4.9670 & 1.59178 \\
Tangible & 40 & 1.00 & 2.00 & 2.0750 & 1.91775 \\
Empathy & 40 & 1.00 & 5.00 & 4.8500 & 2.25230 \\
Responsiveness & 40 & 1.00 & 5.00 & 4.9650 & 1.14030 \\
Valid N (listwise) & 40 & & & & \\
\hline
\end{tabular}

\section{Source: Authors Computation, 2019}

In assessing the auditing gap within Bank, external auditors revealed that they were reliable in their service delivery. Thus, strongly agreeing that external auditor ensures organization follow the due auditing procedure as recommended. Also, external auditors are dependable when handling organization problems. Again, external auditors are people they can trust with organization confidentiality and lastly, external auditors ensure that organization does not spend too much time waiting in queues and where there are delays explanations are given. The mean for this item is 4.880 approximately 5 (strongly agreed).

Additionally, in assessing the auditing gap within Bank, Table 4.4 above revealed that external auditors assured organization of good service delivery. Thus, external auditors were courteous and friendly to organization. Also, external auditors were able to inspire trust and confidence in organization. Again, external auditors ensure that, auditing processes are carried out on time and that no mistakes are made with the process. Lastly, external auditors create a friendly atmosphere for organization to feel safe and relaxed. The mean for this item is 4.9 approximately 5 (strongly agree).

Furthermore, Table 4.4 above revealed that respondents disagreed with the statement that, the bank was tangible in its delivery of service. Thus, external auditors are well dressed at all times with the bank not operating with modern medical equipment. Also, external auditors do not have visually attractive and comfortable physical facility (i.e chairs, beds, table) with no appealing materials (i.e brochures, magazines, newspapers etc) to engage organization as they wait. Lastly, there were no directional signs to help organization with easy navigation and also the bank structures were disability unfriendly, the mean for this item is 2.0 approximately 2 (agreed).

Moreover, Table 4.4 above revealed that respondents strongly agree with the statement that external auditors were empathic in their service delivery. Thus, External auditors were organization when dealing with organization and also were reluctant when responding to organization complaints. Again, external auditors take time to listen to organization and remember names and faces of organization. Lastly, external auditors ensure organization feel good emotionally and psychologically.

The mean for this item is 4.86 approximately 4 (agreed). Lastly, table above revealed that respondents strongly agreed with the statement that external auditors were responsive in their service delivery. Thus, external auditors were always able and ready to receive organization and willing to help organization even during odd hours. Lastly, external auditors have organization interest at heart. The mean for this item was 4.9 approximately 5 (strongly agree). In summary the auditing gap identified here was the tangibility service. 
4.3 Determining the gap between what external auditors perceived and their expectation Table 4.5: gap between what external auditors perceived at the bank and their expectation

\begin{tabular}{|l|c|c|c|}
\hline \multicolumn{1}{|c|}{ Services } & Mean perception & of expectation & $\begin{array}{l}\text { Difference between mean of } \\
\text { perception and expectation }\end{array}$ \\
\hline Reliability & 4.8800 & 4.2120 & 0.67 \\
Assurance & 4.9670 & 4.8160 & 0.16 \\
Tangible & 2.0750 & 3.5520 & -1.47 \\
Empathy & 4.8500 & 4.0960 & 0.75 \\
Responsiveness & 4.9650 & 4.0200 & 0.95 \\
Valid N (listwise) & & & \\
\hline
\end{tabular}

\section{Source: Authors Computation, 2019}

In assessing the auditing gap within Bank, table above established that, in terms of reliability of service delivery external auditors' expectation was lower than expectation on assurance. Thus, indicating that once external auditors are reliable to organization there is an assurance of good service delivery. This expectation was also realised at the bank thereby resulting a positive gap of 0.67 and 0.16 . Additionally, the analysis recognized that, in terms of tangibility of service delivery by the bank, external auditors' expectation was high.

Thus, indicating that external auditors are more particular about the bank structures and facilities given that once the facilities are available, they can satisfy organization. This expectation was not realised at the bank thereby resulting in a negative gap of -1.47 . Lastly, the analysis recognized that, in terms of empathy and responsiveness of service delivery by external auditors, nurse expectation was lower than expected. This implies that, external auditors' immediate responds to organization was slightly not paramount in service delivery and that more was not expected. This expectation was also realised producing a positive gap of 0.95 .

4.4 Comparing the auditing gaps of external auditors and that of staff.

Table 4.7: Comparing the auditing gaps of external auditors and that of organization at bank.

\begin{tabular}{|l|c|c|}
\hline \multicolumn{1}{|c|}{ Services } & Auditing gap of Staff & Auditing gap of external auditors \\
\hline Reliability & 0.34 & 0.67 \\
Assurance & 0.03 & 0.16 \\
Tangible & 0.41 & -1.47 \\
Empathy & -1.30 & 0.75 \\
Responsiveness & 0.03 & 0.95 \\
Valid N (listwise) & & \\
\hline
\end{tabular}

\section{Source: Authors Computation, 2019}

By comparing the auditing gap of external auditors and organization within Bank, the analysis recognized that, in terms of reliability of service external auditors' expectation was quite lower than organization expectation thereby resulting in a higher gap in the view of external auditors than in the views of organization. Additionally, the analysis recognized that, in terms of assurance of service delivery external auditors' expectation was quite lower than Staff expectation thereby resulting in a higher gap in the view of external auditors than in the views of organization. Thus, external auditors need not to expect more given that they were already aware of how assured they were to organization.

Furthermore, the analysis established that, in terms of tangibility of service delivery by the bank, external auditors' expectation was higher than Staff expectation thereby resulting in a negative gap in the view of external auditors and positive in the views of organization. Thus, the organization was not expecting more from the bank facilities but rather from the external auditors since they are the point of auditing activities at the bank. Alternatively, organizations are of the view that, once they are treated well by the external auditors the bank facilities are immaterial. But external auditors' expectation on tangibility was high given that they needed Morden and standard facilities necessary to satisfy organization.

Moreover, the analysis recognized that, in terms of empathy of service delivery by external auditors, expectation was lower than Staff' expectation thereby resulting in a negative gap in the view of organization and positive gap in the views of external auditors. Thus, more was expected from external auditors by organization in terms of empathy but external auditors already aware of their ability were not expecting much from themselves. Lastly, the story was not different in terms of responsiveness of service delivery. In summary, Staff' expectation on external auditors was higher than that of the bank facilities. Also, external auditors' expectation on their service delivery was lower than their expectation on the bank facilities. 


\subsection{Analysis on factors influencing the effectiveness of external auditors}

According to the mean analysis in table 4.8 below, respondents agreed that, external auditors' remuneration was one of the factors that contribute to effectiveness of external auditors. Thus, if external auditors are not well remunerated, their attitude towards job and organization changes negatively causing a gap in auditing. Also, training of external auditors was one of the vital factors contributing to effectiveness of external auditors. Thus, if external auditors are not properly trained their skills and organization relationship becomes limited. There was a lot of variety in their job causing them to enjoy working under less supervision. Again, they feel the level of logistics given to them was play a vital role in the effectiveness of external auditors.

Additionally, the major factor that is likely to be created will certainly emanate from the loyalty rate of external auditors. Thus, if external auditors are not loyal their attitude towards organization negatively changes. Again, attractive motivational package and improved salary immensely contribute to effectiveness of external auditors. Thus, a well-motivated auditor is a happy and welcoming. Lastly external auditors agreed that making their opinion counts in the organisation contributes to effectiveness of external auditors.

Table 4.8: Descriptive Statistics on the reason for the existence of auditing expectation gaps

\begin{tabular}{|l|c|c|c|c|c|}
\hline & $\mathrm{N}$ & Minimum & Maximum & Mean & Std. Deviation \\
\hline Remuneration of external auditors & 200 & 1.00 & 4.00 & 4.0400 & 2.03941 \\
Training of external auditors regularly & 200 & 1.00 & 4.00 & 3.6700 & 1.59178 \\
Appropriate logistics for external auditors & 200 & 1.00 & 4.00 & 4.0750 & 1.91775 \\
External auditors loyalty rate & 200 & 1.00 & 5.00 & 4.8500 & 2.25230 \\
Attractive motivational packages & 200 & 1.00 & 4.00 & 3.9650 & 1.14030 \\
Improved salary & 200 & 1.00 & 4.00 & 4.0400 & 2.03941 \\
Morden banking technology & 200 & 1.00 & 4.00 & 3.6700 & 1.59178 \\
Opinion counts. & 200 & 1.00 & 4.00 & 4.0750 & 1.91775 \\
Valid N (listwise) & 200 & & & & \\
\hline
\end{tabular}

4.6 Relationship between unethical behaviours and corporate failure

Table 4.9 Regression Model Summary

\begin{tabular}{|l|l|l|l|c|}
\hline Model & R & R Square & Adjusted R Square & Std. Error of the Estimate \\
\hline 1 & $.915^{\mathrm{a}}$ & .837 & .818 & .10087 \\
\hline
\end{tabular}

a. Predictors: (Constants) unethical behavior

Table 4.9 above provides the $\mathrm{R}^{2}$ (coefficient of determination or predictive power) value. The $\mathrm{R}^{2}$ value is 0.837 representing a good correlation. The value indicates a strong degree of determination. When the $\mathrm{R}^{2}$ value falls between .70 and .90 it is considered a strong correlation. The $\mathrm{R}^{2}$ value indicates how much of the dependent variable corporate failure can be explained by the independent variables unethical behavior. In this case, $83.7 \%$ can be explained, which is strong. Thus, corporate failure does not occur by chance but rather based on the audit services at the Bank.

Table 4.10 ANOVA of regression

\begin{tabular}{|l|c|c|c|c|c|}
\hline Model & Sum of Squares & Df & Mean Square & F & Sig. \\
\hline $1 \quad$ Regression & 5.398 & 15 & .360 & 35.363 & $.000^{\mathrm{a}}$ \\
Residual & 1.007 & 99 & .010 & & \\
Total & 6.405 & 114 & & & \\
\hline
\end{tabular}

a. Predictors: (Constant), unethical behaviour

b. Dependent Variable: corporate failure

Table 4.10 above indicates ANOVA of regression. The ANOVA indicates how well the independent variables significantly predict the outcome variable which is corporate failure. The Sig. value on the regression row indicated 0.00 which is less than the confidence interval of 0.05 and indicates that, the model applied is significantly good enough in predicting the outcome variable (corporate failure). 
Table 4.11: coefficient of regression

\begin{tabular}{|l|c|c|c|c|c|}
\hline \multirow{2}{*}{ Model } & \multicolumn{2}{|c|}{ Unstandardized Coefficients } & Standardized Coefficients & & \\
\cline { 2 - 5 } & $\mathrm{B}$ & Std. Error & Beta & $\mathrm{T}$ & Sig. \\
\hline 1 (Constant) & .937 & .209 & & 4.480 & .000 \\
Unethical behaviors & .274 & .021 & .484 & 12.912 & .000 \\
& & & & & \\
\hline
\end{tabular}

a. Dependent Variable: corporate failure

\subsubsection{Regression equation}

From the coefficients table 4.11 above, the Level of corporate failure can be explain using the unethical behavior highlighted in the coefficient table. Unethical behaviors here are the service delivery which was negatively responded by respondent for instance in estimating the level of corporate failure in the case of confidentiality: predicted Level of corporate failure $=0.937+0.274 \mathrm{x}$ (Unethical behavior). Thus, if external auditors are not confidential then the impact on corporate failure will be high. According to the regression model, unethical behavior has a positive relationship with corporate failure. The results from this study is in support of Annuar, et al. (2001) who opined that the internal auditors should provide information on important factors that contribute towards the effectiveness of an internal audit. Interpersonal skills, internal auditor's commitment and support from audit committee and board of directors, audit performance and integrity, audit department efficiency, auditing competencies, internal auditor's knowledge on company's business operation and industry and auditor's independence are found to be important attributes contributing towards internal audit function effectiveness. Annuar, et al. (2001 opined that unethical behaviour of auditors will contribute to corporate failure.

\subsection{Conclusion}

In conclusion the study recognized the difference between the mean perception and expectation of external auditors and that of staff at the Banks. The analysis indicates that, the external auditing gap from the views of external auditors was about tangibility service whiles that of Staff was about empathy of service delivered by external auditors at the Bank.

The auditing gaps within bank were tangibility and empathy services. Additionally, the study revealed that remuneration, training of external auditors, lot of variety in their job, level of logistics, loyalty rate of external auditors, motivational package and improved salary and opinion counts in the organisation were the factors influencing the effectiveness of external auditors. Lastly, unethical behavior has a positive relationship with corporate failure which was statistically significant at confident interval of 0.05 with a predictive power of 83.7 percent chance of predicting corporate failure which was moderate.

\subsection{Recommendations}

Based on the findings set out above, it is recommended that the Bank adopts the following measures as means of improving the conduct of corporate failure audit in Ghana.

Steps should be taken to train and promote external auditors towards acquiring the necessary skills and experience to commission the corporate failure audit. Additionally, assistance also could be sought from other Supreme Audit Institutions in other countries with a similar government arrangement. Alternatively, assistance from private audit firms that have developed expertise in the public sector audit can be sought to assist them to make the audit function more meaningful and constructive. This will help fill the empathic gap of clients.

Again, it is recommended that the bank establishes the formal communication mechanisms such as organizing forums and dialogue to obtain feedback from user groups on the conduct of corporate failure audits. This formal communication channels would allow external auditors to identify users' information needs which in turn would enable them to fulfill their reporting responsibilities more effectively. Also, auditors should be well resourced in their operation given that tangibility was a gap in the study.

Finally, with the current trend towards the harmonization of auditing standards and guidelines, further research into the usefulness and adequacy of auditing standards and guidelines is worthwhile. Considering that the objective of corporate failure audit is to provide the information on the status of the activity or program, present auditing standards and guidelines should be examined to ensure that they truly assist in the generation of audit report and audit process. The finding of this study shows that there is a need for more research on the effect of auditing gaps on the corporate failure organization.

\section{References}

Abbot, A. (1983). Professional ethics, American Journal of Sociology, Vol. 88(5), pp. 855-885.

Abdullah, H. S. (1988). Corporate failure auditing: A brief survey of its definition and the practice in Malaysia, 
Jurnal Parlimen Malaysia. Vol. 11(4), p. 24-28.

Abdul-Rahman, H. and Alidrisyi, M. N. (1994). A perspective of material management practices in a fastdeveloping economy: the case of Malaysia, Construction Management and Economics, Vol. 12, pp. 413-422.

Abraham, S. (1993). Sejarah Perkembangan Negara, Kuala Lumpur: Penerbit Fajar Bakti.

Agacer, G. M. and Doupnik, T. S. (1991). Perceptions of auditor independence: A cross-cultural study, International Journal of Accounting, Vol. 26, pp. 220-37.

Agyemang, J.K., Wingard, C,H. and Acheampong, O. (2019). Fair Value Accounting in the Agricultural Sector: The Analysis of Economic and Educational Factors, Asian Journal of Economics, Business and Accounting, 9(4): 1-13, 2018; Article no.AJEBA.46763

Ahmad, N. N. and Abdul-Rahim, N. L. A. (2003). Awareness of the concept of corporate social responsibility among Malaysian managers in selected public listed companies, paper presented at The Seventh International Conference on Global Business and Economic Development, Thailand, 8-12 January, 2003.

Aldridge, A. and Levine, K. (2001). Surveying the Social World: Principles and Practice in Survey Research, Buckingham: Open University Press.

Alhabshi, S. O. (1996). Transparency and accountability in the Malaysian public sector, paper presented at the Fifth International Conference on Public Sector Ethics: Between Past and Future, Queensland, 5-9 August, 1996.

Ali, A. (1999), The Political Economy of External Auditing in Malaysia, 1957-1997, Sintok: Universiti Utara Malaysia Press.

Al-Jader L. N., Parry Langdon N., Smith, R. J. (2000). Survey of attitudes of pregnant women towards Down Syndrome screening. Prenatal Diagnosis, Vol. 20, pp. 23-29.

Allen, G. C. and Donnithorne, A. G. (1954). Western Enterprise in Indonesia and Malaya, A Study in Economic Development, London: George Allen \& Unwin.

264

Allen, R. (1968). Malaysia: Prospect and Retrospect. The Impact and Aftermath of Colonial Rule, London: Oxford University Press.

Allen-Meares, P. and Lane, B. A. (1990). Social work practice: Integrating qualitative and quantitative data collection techniques, Social Work, Vol. 35, pp. 452-458.

Alleyne P. A., Devonish D. and Alleyne P. (2006). Perceptions of auditor independence in Barbados, Managerial Auditing Journal, Vol. 21 (6), pp. 621-635.

Aslam, M. and Hassan, A. A. (2003). Development planning and regional imbalances in Malaysia. Working Paper, Faculty of Economic and Administration, University of Malaya.

Athukorala, P. and J. Menon (1999). Outward orientation and economic development in Malaysia, World Economy, Vol. 22(8), pp. 1119-1139.

Awang A. H. (1984). Overview of the Urban Planning System in Malaysia. Department of Urban and Regional Planning, Universiti Teknologi Malaysia, Kuala Lumpur.

Ball, R. (1998). Corporate failure Review in Local Government, Aldershot: Ashgate.

Barrett, P. (1996). Some thoughts about the roles, responsibilities and future scopes of External auditors-General, Australian Journal of Public Administration, Vol 55(4), pp. 137-146.

Barzelay, M. (1997). Central Audit Institutions and Corporate failure Auditing: A Comparative Study of Organizational Strategies in the OECD, Governance: An International Journal of Policy and Administration, Vol.10, pp. 253-260.

Baydoun, N. and Willet, R. (1995). Cultural relevance of western accounting system to developing countries, Abacus, Vol. 31(1), pp. $67-92$.

Beattie, V. and Fearnley, S. (1998). Auditor changes and tendering: UK interview evidence, Accounting, Auditing \& Accountability Journal, Vol. 11(1), pp.72-98.

Beattie, V., Brandt, R. \& Fearnley, S. (1999). Perceptions of auditor independence: U.K. evidence, Journal of International Accounting Auditing and Taxation, Vol. 8(2), pp. 67-107.

Berg, B. L. (1995). Qualitative Research Methods for the Social Sciences, 2nd edition, Boston: Allyn and Bacon. 265

Berglof, E., and von Thadden, E. (1999). The changing corporate governance paradigm: implications for transition and developing countries, paper presented at the Annual World Bank Conference on Development Economics, Washington DC, 28-30 April, 1999.

Berita Harian (2002). Ketua audit diminta elak laporan sensasi, 8 October, 2002.

Boyd, D. T., Boyd, S. C. and Boyd, W. L. (2001). The audit report: A misunderstanding gap between users and preparers, National Public Accountant, pp. 56-60.

Brewer, J. and Hunter, A. (1989). Multimethod Research: A Synthesis of Styles, CA: Sage Publication. Brown, I. (1986). Malaysia, Oxford: Clio Press.

Brown, R. (1985). On the State of Auditing: Analysis; Reflections, Public Budgeting and Finance, Summer, pp. 
$75-88$

Brown, R. G. (1962). Changing audit objectives and techniques, The Accounting Review, Vol. 37(4), pp. 696-703.

Bryman, A. (1998). Quantity and Quality in Social Research, London: Unwin Hyman.

Bryman, A. (2001). Social Research Methods, Oxford: Oxford University Press.

Buang, A. (2007). Emerging issues and global challenges in the public sector audit in the 21st Century: Malaysian Perspective, National Audit Department Seminar Paper.

Burns, R. (1990). Introduction to Research Methods in Education, Melbourne: Longman Cheshire.

Butt, H. A. and Palmer, D. R. (1985). Value for Money in the Public Sector: The Decision Makers Guide, Oxford: Blackwell.

Cadbury Committee (1992), Report of the Committee on the Financial Aspects of Corporate Governance, London: Gee.

Candy, P. (1991). Self-Direction For Lifelong Learning. San Francisco: Jossey-Bass. 266

Cannell, C. F. and Kahn, R. L. (1953). The collection of data by interviewing in Festinger, L. and Katz, D. (eds). Research Methods in the Behavioural Sciences, New York: The Dryden Press, pp. 327 - 380.

Canning, M. and Gwilliam, D. (1999). Non-audit services and auditor independence: Some evidence from Ireland, The European Accounting Review, Vol. 8(3), pp. 401-419.

Cassell, C. and Symon, G. (1994). Qualitative Methods in Organisational Research: A Practical Guide, London: Sage Publication.

CCAF, (1996), Accountability, Corporate failure Reporting, Comprehensive Audit - An Integrated Perspective, Ottawa: Canadian Comprehensive Auditing Foundation.

Chand, P. (2005). Convergence of accounting studies in the South Pacific Island Nations, The case of Fiji, The Journal of Pacific Studies, Vol. 28(2), pp. 269 - 290.

Chang, H. J. (2001). Institutional Development in Developing Countries in a Historical Perspective: Lessons from Developed Countries in Earlier Times, paper presented at the European Association of Evolutionary Political Economy (EAEPE) Annual Meeting, Siena, Italy, 8-11 November, 2001.

Chenail, R. J. (1995). Presenting Qualitative Data, The Qualitative Report, Vol. 2(3). Available at: (http://www.nova.edu/ssss/QR/QR2-3/presenting.html).

Chowdhury, R. and Innes, J. (1998). A qualitative analysis of the audit expectations gap in the public sector of Bangladesh, International Journal of Auditing, November, pp. 247-61.

Chowdhury, R. R. (1996). Audit Expectation Gap in the Public Sector of Bangladesh, Unpublish PhD thesis, Department of Accountancy and Business Finance, University of Dundee.

Chowdhury, R., Innes, J. and Kouhy, R. (2005). The public sector audit expectations gap in Bangladesh, Managerial Auditing Journal, Vol. 20(8), pp. 893-908.

CICA. (1988). Report of The Commission to study the public's expectation of audits, Canada: Canadian Institute of Chartered Accountants.

CICA. (2000). Audit Enquiry: Seeking More Reliable Evidence from Audit Enquiry, Toronto: Canadian Institute of Chartered Accountants.

267

Clarke, A. and Dawson, R. (1999). Evaluation Research: An Introduction to Principles, Methods, and Practice, London: Thousands Oaks.

Comptroller and Auditor General. (2000). Corporate failure Audit Manual, Dhaka: Office of the Comptroller and Auditor General of Bangladesh.

Creswell, J. W. (1994). Research Design: Qualitative and Quantitative Approaches, Thousand Oaks, CA: Sage Publications.

Creswell, J. W. (2002). Educational Research: Planning, Conducting, and Evaluating Quantitative and Qualitative Research, Upper Saddle River, NJ: Merrill Prentice Hall.

Creswell, J. W. (2003). Research Design: Quantitative and Qualitative Approaches, 2nd edition, Thousand Oaks, CA: Sage Publications.

Creswell, J. W. and Miller, D. L. (2000). Determining validity in qualitative inquiry, Theory into Practice, Vol. 39(3), pp. 124-131.

Crotty, M. (1998). The Foundations of Social Research: Meaning and Perspective in the Research Process, CA: Sage Publication.

Cutt, J. (1988). Comprehensive Auditing in Canada: Theory and Practice, New York: Praeger. 